\title{
IDENTIFIKASI ISI LAMBUNG IKAN KEPAET Osteochilus sp. ASAL PULAU BANGKA SEBAGAI DASAR PENGEMBANGAN DOMESTIKASI
}

\section{STOMACH CONTENT IDENTIFICATION OF KEPAET FISH Osteochilus sp. FROM BANGKA ISLAND FOR PRINCIPLE OF DOMESTICATION DEVELOPMENT}

\author{
Ulfa Dwinda Icas ${ }^{1}$, Ahmad Fahrul Syarif ${ }^{1, *}$, Eva Prasetiyono1, Ardiansyah Kurniawan ${ }^{1,2}$ \\ ${ }^{1}$ Jurusan Akuakultur, Fakultas Pertanian Perikanan dan Biologi, Universitas Bangka Belitung, Indonesia \\ ${ }^{2}$ Mahasiswa Doktoral Ilmu Perikanan dan Kelautan, Fakultas Perikanan dan Ilmu Kelautan, Universitas \\ Brawijaya, Indonesia \\ •email penulis korespondensi: ahmadfahrulsyarif@gmail.com
}

\begin{abstract}
Abstrak
Ikan Kepaet merupakan salah satu spesies ikan lokal yang ditemukan di sungai-sungai pulau Bangka. Ikan Kepaet memilki kemiripan dengan ikan Cempedik yang berasal dari Pulau Belitung. Karakteristik ikan ini adalah titik hitam pada bagian ekor dan warna tubuh keperakan. Ikan ini berpotensi sebagai speses akuakultur, sehingga perlu dilakukan penelitian tipe makanan alaminya. Tujuan dari penelitian ini adalah mendeskripsikan jenis makanan yang terdapat dalam lambung ikan Kepaet dan menjelaskan tipe kebiasaan makan ikan ini. Hasil penelitian ini menunjukkan bahwa makanan utama ikan Kepaet adalah Synedra (Bacillariophyta) dengan nilai IP 57,56\%, Nitzchia 20,16\%, Closterium 11,45\% Aulacoseira 8\% dan jenis makanan tambahan lain yaitu Gyrosigma, Rhizosolenia, Melosira, and Selenastrum dengan nilai IP 0,06\%$0,38 \%$. Ikan Kepaet tergolong dalam kelompok ikan herbivora karena berdasarkan panjang usus relatifnya adalah 3,57.
\end{abstract}

Kata Kunci: Ikan kepaet, Osteochillus sp, Kebiasaan makan, Isi lambung, Panjang usus relatif

\begin{abstract}
Kepaet fish is the one of local fish species found in rivers of Bangka Island. Kepaet fish has similarity with Cempedik from Belitung Island. The characteristic of this fish is a black spot near its tail and a silver scales color. This fish has potentially for aquaculture species, so its needs to to find out the type of natural feed. The purpose of this study aimed to describe the types of food in stomach contents of Kepaet fish and to expalined the types of feeding behaviour. The results showed that the main food of Kepaet fish is Synedra (Bacillariophyta) with IP value 57,56\%, Nitzchia (Bacillariophyta) 20,16\%, Closterium $11,45 \%$ and Aulacoseira 8\% and complementary food is Gyrosigma, Rhizosolenia, Melosira, and Selenastrum with between IP Value 0,06\%- 0,38\%. Kepaet fish belongs to the herbivore fish group because has the relative length of the gut is 3,57.
\end{abstract}

Keywords: Kepaet fish, Osteochillus sp, Feeding behaviour, Stomach contents, Relative length of the gut

\section{PENDAHULUAN}

Ikan Kepaet merupakan salah satu ikan lokal yang banyak terdapat di perairan Pulau Bangka. Ikan ini terkenal sebagai ikan konsumsi bagi masyarakat. Ikan ini memiliki nilai ekonomis yang rendah untuk masyarakat pulau Bangka (Kurniawan et al., 2016). Ikan Kepaet juga ditemukan di Sungai Jeruk (Juwita, 2015), Sungai Penyerang (Gustomi, 2010), Sungai Menduk dan Sungai Lelabi (Muslih, 2011; Kurniawan, 2016).

Ikan Kepaet yang berasal dari Pulau Bangka khususnya Sungai Lelabi memiliki similaritas
70,6\% persamaannya dengan ikan Cempedik Pulau Belitung (Kurniawan, 2016). Hal ini memungkinkan ikan Kepaet dapat didistribusikan ke Pulau Belitung sebagai pengganti dan untuk memenuhi kebutuhan akan ikan Cempedik, disamping membatasi penangkapan berlebihan di Pulau Belitung. Potensi ini kemudian menjadikan ikan Kepaet potensial dikembangkan sebagai komoditas akuakultur khas Bangka Belitung. Pengembangan spesies ini dapat dimulai dengan adanya kegiatan 
domestikasi (penjinakan) (Junior, 2003). Menurut Pramudya et al., (2017) karakteristik biologi dalam domestikasi yaitu morfologi, anatomi, kebiasaan makan (food habit), dan habitatnya. Mengetahui kebiasaan makan merupakan salah satu faktor yang mempengaruhi pertumbuhan, reproduksi serta kelangsungan hidup pada ikan yang didomestikasi (Effendie, 1997).

Lambung merupakan organ pencernaan yang berfungsi untuk mencerna makanan sehingga dapat diketahui jenis makanan suatu organisme tertentu. Menurut Taqwa (2012), makanan yang terdapat pada lambung ikan belum tercerna dengan sempurna sehingga masih mudah diidentifikasi jenis organisme makanannya. Sehingga, penelitian ini dilakukan untuk mengkaji kebiasaan makan ikan Kepaet sebagai dasar pengembangan budidaya utamanya adalah kegiatan domestikasi.

\section{MATERI DAN METODE}

\section{Materi Uji}

Pengambilan Sampel ikan Kepaet dilakukan di Sungai Lebak Desa Paya Benua Kabupaten Bangka. Penelitian ini akan dilakukan pada Bulan Mei 2017 bertempat di Laboratorium Akuakultur Fakultas Pertanian, Perikanan dan Biologi Universitas Bangka Belitung. Ikan Kepaet yang digunakan diperoleh dari hasil tangkapan nelayan. Jumlah ikan yang digunakan dalam penelitian ini berjumlah 38 ekor dengan panjang $6,27 \pm 0,63 \mathrm{~cm}$ dan bobot $3,42 \pm 0,83 \mathrm{~g}$.

Ikan Kepaet yang di dapat kemudian diukur panjang total (PT) menggunakan penggaris dan ditimbang bobot tubuhnya (BB) menggunakan timbangan digital selanjutnya, dimasukkan kedalam botol sampel dan direndam dalam larutan formalin 4\% (Effendie, 1979).

\section{Pengamatan Sampel Lambung Ikan}

Ikan Kepaet yang sudah diawetkan menggunakan formalin 4\% dikeluarkan dari botol sampel untuk dicuci menggunakan air mengalir untuk mengurangi kadar formalin pada sampel. Pengambilan lambung ikan Kepaet dilakukan dengan cara membedah perut ikan Kepaet dimulai dari bagian lubang anus hingga operculum menggunakan gunting bedah. Perut ikan Kepaet dibuka untuk menggambil bagian lambung dan usus kemudian dipisahkan dengan bagian organ yang lainnya dengan menggunakan pinset. Usus dipisahkan dari lambung untuk diukur panjang ususnya (PU).

Isi lambung tersebut kemudian diencerkan menggunakan aquades. Isi lambung ikan Kepaet yang sudah diencerkan menggunakan pipet tetes diamati menggunakan mikroskop. Organisme yang diamati kemudian menggunakan buku identifikasi fitoplankton. Data yang didapatkan digunakan untuk menghitung indeks bagian terbesar, yaitu Index of Preponderance (IP) suatu jenis makanan yang dimakan oleh ikan.

\section{Parameter Penelitian}

Index of Proponderance

Rumus perhitungan IP, menurut Titrawani (2011) yaitu :

$$
I P(\%)=\frac{\mathrm{Vix} \mathrm{Oi}}{\Sigma(\mathrm{Vi} \times \mathrm{Oi})} \times 100 \%
$$

Keterangan :

$\begin{array}{ll}\text { IP } & \text { : Index of Proponderance } \\ \text { Vi } & \text { : Persentase volume satu macam } \\ & \text { makanan } \\ \text { Oi } & \text { : Persentase frekuensi satu kejadian } \\ & \text { satu macam makanan } \\ \Sigma V i x \text { Oi }: & \begin{array}{l}\text { jumlah Vi x Oi dari semua macam } \\ \text { makanan. }\end{array}\end{array}$

Panjang usus relatif (PU)

Analisis panjang usus relatif untuk mengetahui tipe makan dari ikan berdasarkan makanan yang dikonsumsinya. Dari analisis ini akan diketahui bahwa ikan tersebut termasuk kelas herbivora, omnivora atau karnivora yang diperoleh berdasarkan perbandingan panjang usus dengan panjang totalnya (Izzani, 2012).

$$
\text { Panjang Usus Relatif }=\frac{\text { Panjang Usus }}{\text { Panjang Tubuh }}
$$

\section{HASIL}

Hasil identifikasi yang telah dilakukan pada isi lambung ikan Kepaet didapatkan 8 jenis makanan yang terdiri dari dua kelas yaitu Bacillariophyta $(88,25 \%)$, Chlorophyta $(11,75)$ dan sisanya adalah jenis yang tidak teridentifikasi. Kelas Bacillariophyta terdiri dari 6 genus yaitu Aulacoseira, Gyrosigma, Synedra, Rhizosolenia, Nitzschia, dan Melosira, sedangkan untuk kelas Chlorophyta terdiri 2 jenis yaitu Selenastrum dan Closterium (Gambar 1).

Berdasarkan perhitungan nilai IP didapatkan bahwa Synedra dari kelas Bacillariophyceae sebagai makanan utama yang memiliki presentase sebesar $57,56 \%$ selanjutnya berturut-turut Nitzchia 20,16\%, Closterium $11,45 \%$ Aulacoseira 8\% dan jenis makanan tambahan lain yaitu Gyrosigma, Rhizosolenia, Melosira, and Selenastrum dengan nilai IP 0,06\%$0,38 \%$. Sedangkan hasil dari perhitungan panjang usus relatif dapat diketahui bahwa ikan Kepaet merupakan jenis herbivora (Tabel 1). 


\section{PEMBAHASAN}

Berdasarkan hasil yang diperoleh tersebut mengindikasikan bahwa bahwa ikan Kepaet merupakan jenis ikan pemakan plankton khususnya fitoplankton. Menurut Umar \& Kartamihardja (2011) kelas Bacillariophyta juga mendominasi $48,6 \%$ di perairan Danau Singkarak, Sumatra Utara. Hal ini menunjukkan bahwa banyak dari ikan-ikan yang bersfat herbivora menjadikan kelas ini sebagai makanan utamanya.

Genus Synedra merupakan diatom dominan diperairan tawar Indonesia baik pada ekosistem lotik dan lentik. Diatom ini mampu mentolerir ekosistem danau ataupun sungai dengan kandungan bahan organik yang tinggi (Samudra et al., 2013). Pada penelitian ini nilai IP yang diperoleh menunjukkan bahwa ikan Kepaet termasuk ke dalam jenis ikan herbivora dengan makanan utamanya adalah kelas Bacillariophyceae. Bacillariophyceae banyak ditemukan di perairan tawar, payau dan laut, sehingga banyak dikonsumsi oleh ikan yang bersifat herbivora. Penelitian Patriono et al., (2005) menyatakan bahwa ikan Sepat Rawa (Trichogaster trichopterus) dikategorikan sebagai sebagai ikan herbivora dengan makanan utamanya yaitu Bacillariophyceae.

Nikolsky (1963) menyatakan bahwa panjang usus relatif ikan karnivora yaitu $<1$, untuk panjang usus ikan omnivora panjang usus relatifnya 1-3 dan untuk panjang usus relatif $>3$ termasuk dalam ikan herbivora. Dalam penelitian Syahputra et al. (2014) rerata panjang usus relatif ikan Sepat (Trichogaster trichopterus) sebesar 4,52. Panjang usus ikan vegetaris (pemakan sejenis tumbuhan) dapat mencapai 3 kali dari panjang total tubuhnya (Asyari \& Fatah, 2011). Panjang usus pada ikan herbivora lebih panjang dibandingkan ikan omnivora dan karnivora sebab dalam mencerna makanan sejenis tumbuhan memerlukan waktu yang lama.

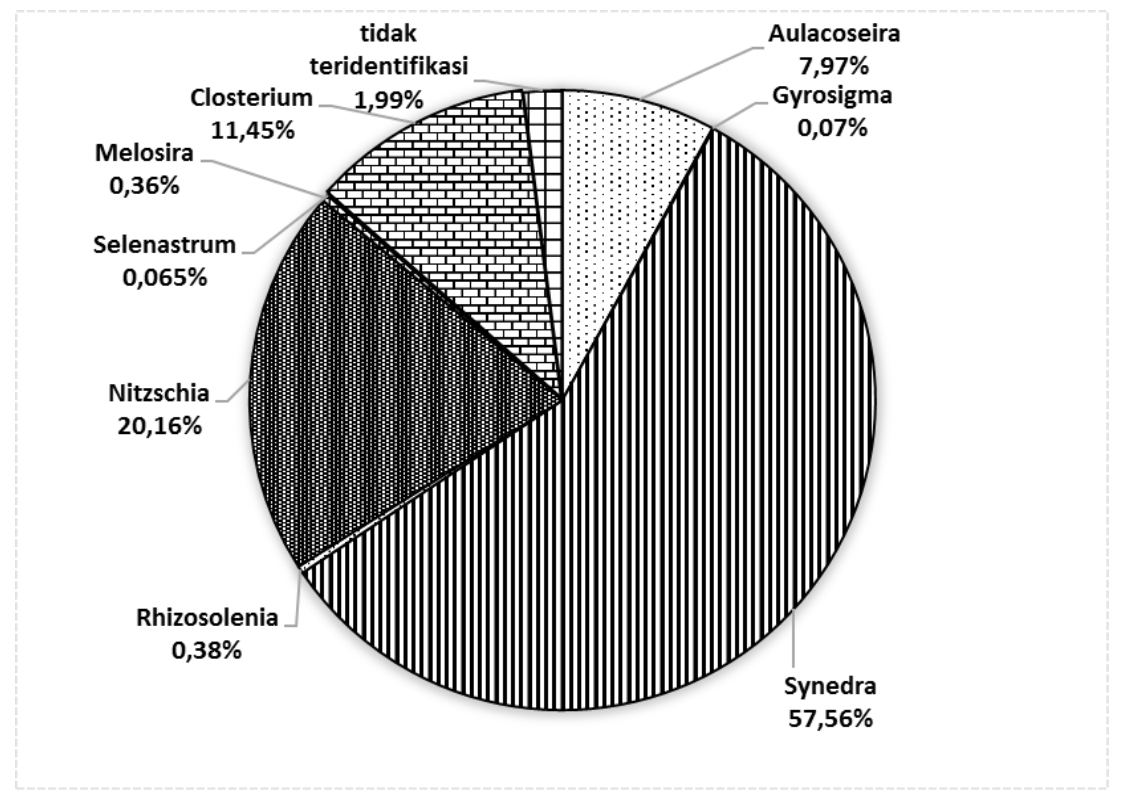

Gambar 1. Diagram Index of Propenderance Isi Lambung Ikan Kepaet (Osteochillus sp).

Tabel 1. Perhitungan panjang usus relatif (PU) ikan kepaet (Osteochillus sp.)

\begin{tabular}{ccc}
\hline Kisaran panjang total ikan (cm) & Kisaran panjang usus (cm) & Panjang usus : Panjang total \\
\hline $6,20 \pm 0,64$ & $22,21 \pm 3,90$ & 3,57 \\
\hline
\end{tabular}

\section{KESIMPULAN}

Jenis makanan yang terdapat di dalam lambung ikan Kepaet adalah jenis fitoplankton dengan dominansi organisme yang ditemukan adalah Genus Synedra (Bacillariophyceae). Ikan Kepaet termasuk ke dalam kelompok ikan herbivora dengan panjang usus relatif adalah 3,57 .

\section{DAFTAR PUSTAKA}

Asyari, Fatah K. 2011. Kebiasaan makan dan biologi reproduksi ikan Motan (Thynnichthys polylepis) di Waduk Kotopanjang, Riau. J. BAWAL 3(4): 1-11

Effendie MI. 1979. Metode biologi perikanan. Yayasan Dewi Sri. Bogor. 112p 
Effendie MI. 1997. Biologi perikanan. Yayasan Pustaka Nusatama. Yogyakarta. 159p

Izzani N. 2012. Kebiasaan makan ikan tembang (Sardinella fimbriata Cuvier and Valenciennes 1847) dari Perairan Selat Sunda yang didaratkan di PPP Labuan, Kabupaten Pandeglang, Banten. [Skripsi]. Fakultas Perikanan dan Ilmu Kelautan. Institut Pertanian Bogor

Juwita. 2015. Keanekaragaman jenis ikan di Sungai Lelabi, Bangka Barat. [Skripsi]. Fakultas Pertanian, Perikanan dan Biologi. Universitas Bangka Belitung

Kurniawan A. Kurniawan A. Fakhrurrozi Y. 2016. Kekerabatan genetik ikan Cempedik Sungai Lenggang dan Langkang, Belitung Timur dengan ikan Kepaet Sungai Lelabi, Bangka Barat menggunakan RAPD. Seminar Nasional Perikanan dan Kelautan VI. Fakultas Perikanan dan Kelautan, Universitas Brawijaya Malang

Muslih K. Adiwilaga ME. Adiwibowo S. 2014. Pengaruh penambangan timah terhadap keanekaragaman ikan sungai dan kearifan lokal masyarakat di Kabupaten Bangka. J. Limnotek 21(1): 52-63

Muslih K. 2014. Pengaruh penambangan timah terhadap keanekaragaman ikan sungai dan kearifan lokal masyarakat di Kabupaten Bangka. [Tesis]. Institut Pertanian Bogor

Nikolsky GV. 1963. The Ecology of Fishes. Academic Press: New York. 352p

Patriono E. Anggraini D. Nofyan E. 2005. Studi komposisi fitoplankton sebagai pakan alami ikan Sepat Rawa (Trichogaster trichopterus) stadium muda di Lebak Lebung Teloko Sumatra Selatan. Prosiding Forum Perairan Umum Indonesia ke-1: 149-153

Samudra SR. Soeprobowati TR. Izzati M. 2013. Komposisi, Kelimpahan dan Keanekaragaman Fitoplankton Danau Rawa Pening Kabuaten Semarang. J. Bioma 15(2): 6-13

Syahputra H. Bakti D. Kurnia MR. 2014. Studi komposisi makanan ikan Sepat Rawa (Trichogaster trichopterus) di rawa tergenang Desa Marindal Kecamatan Patumbak. J. Aquacoast Marine 4(5): 111120

Taqwa. Hukama F. Nurdawati, S. Irawan C. 2012. Kebiasaan makan ikan betok (Anabas testudineus) di Rawa Banjiran Desa Talang Paktimah Kabupaten Muara Enim Sumatera Selatan. J. AGRIA 7(2): 170-174

Titrawani E. Roza U. Sawalia R. Analisis isi lambung ikan senangin (Eleutheronema tetradactylum Shaw) di Perairan Dumai. J. Biologi 6(2): 85-90
Umar C. Kartamihardja ES. 2011. Hubungan panjang-berat, kebiasaan makan dan kematangan gonad ikan bilih (Mystaecoleucus padagensis) di Danau Toba, Sumatra Utara. J. BAWAL 6(3): 351356 